Tytova, N. M. (2018). Vykorystannia partysypatyvnoho pidkhodu u psykholoho-pedahohichnii pidhotovtsi pedahohiv profesiinoho navchannia [Use of participatory approach in psychological and pedagogical training of vocational training teachers]. World Science, 7 (35), Vol. 1. Warsaw (Poland): RS Global Sp. z O.O [in Ukrainian].

\title{
BORISOVA T.
}

Poltava V. G. Korolenko national pedagogical University, Ukraine

\section{INNOVATIVE APPROACHES TO THE IMPLEMENTATION OF ERGODESIGN TECHNOLOGIES IN EDUCATIONAL INSTITUTIONS}

Our research substantiates the content of ergodesign technologies and the importance of innovative methodological approaches (transparent, participatory and diversified) to the implementation of ergodesign technologies in the educational environment.

Ergodesign technologies as a symbiosis of scientific research of ergonomics and design require a comprehensive approach to determining the prospects for their use in order to improve the educational environment. To improve the educational environment of special importance are technology ergodesign learning environment, technology ergodesign physical processes in the educational environment, technology of ergodesign cognitive sphere, technology ergodesign educational communications and technology ergodesign information educational environment.

The definition of innovative scientific and methodological approaches to the implementation of ergodesign technologies in educational institutions contributes to the solution of certain problems to ensure comfortable conditions for the implementation of educational activities of students and pedagogical activities of the teacher. Among the innovative methodological approaches, our study highlights transparent, participatory and diversified approaches, which does not limit the range of methodological approaches and requires further study and justification. On the basis of a transparent approach, the transparency, accessibility and openness of the organization of educational processes based on ergodesign technologies are justified. The participatory approach reflects the active position of all participants in the educational process in order to achieve consensus on various issues to improve the educational process by means of ergodesign technologies. The diversification approach reveals various areas of influence of ergodesign technologies on the organization and implementation of educational processes.

The analysis of scientific works of pedagogical and methodological nature, as well as scientific reflections presented in our study, prove that ergodesign technologies contribute to a comprehensive approach to improving many factors for the successful implementation of educational and pedagogical activities of individuals in educational institutions.

Keywords: ergodesign; educational environment; ergodesign technologies; ergodesign of the educational environment; innovative methodological approaches to the implementation of ergodesign technologies in educational institutions: transparent, participatory, diversified

Стаття надійшла до редакції 22.10.2019 р.

УДК 159.9:37]:001-026.15

DOI: https://doi.org/10.33989/2075-146x.2019.24.194591

\section{СТАНІСЛАВ БУРЧАК}

ORCID ID 0000-0002-1641-3251

Глухівський національний педагогічний університет імені Олександра Довженка

\section{ГЕНЕЗА ПРОБЛЕМИ КРЕАТИВНОСТІ В ПСИХОЛОГО-ПЕДАГОГІЧНІЙ НАУЦІ}

\begin{abstract}
У статті розкрито процес становлення поняття креативності особистості, технологій ії розвитку та діагностування з античних часів до сьогодення. Проаналізовано психолого-педагогічні літературні джерела з метою виявлення різноманітних підходів до трактування поняття «креативність». Розглянуто підходи сучасних науковців до означення поняття креативності, їі структурних складників (компонентів), методик оцінки рівня розвитку окремих креативних якостей особистості, в тому числі й щодо педагогічних працівників.
\end{abstract}

Ключові слова: ґенеза проблеми креативності; психолого-педагогічна наука; креативність особистості; методика оцінки креативності; компоненти креативності; креативність майбутнього вчителя

Постановка проблеми в загальному вигляді та вказівка на їі зв'язок із важливими науковими чи практичними завданнями. Провідна ідея сучасної педагогічної освіти - формування педагога-професіонала, який відзначатиметься компетентністю та мобільністю, самостійністю й ініціативністю, нестандартним мисленням і творчим підходом до роботи, індивідуальним методичним стилем і вмінням організовувати освітній процес 3 урахуванням потреб та особливостей кожного учня. Нові цінності та орієнтири освіти (індивідуально-особистісний підхід у навчанні, суб’єкт-суб’ єктні відносини вчителя та учнів і т.д.), а також сучасні досягнення науки багато в 
чому визначають вибір технологій, яким педагоги все частіше віддають перевагу на цьому етапі розвитку освіти (Павленко, 2016, с. 184).

Виникає потреба в застосуванні креативних форм, методів навчання, які розвивають здатність до оригінальної думки та креативної дії. Звідси найважливішим завданням освітніх систем є забезпечення творчого розвитку особистості, про що наголошується у численних освітніх документах нашої держави. Зокрема, у Державній національній програмі «Освіта» (Україна XXI століття) одним із стратегічних завдань окреслено створення умов для формування освіченої, творчої особистості громадянина, реалізації та самореалізації його природних задатків і можливостей в освітньому процесі (Державна національна програма «Освіта», 1994). У Національній доктрині розвитку освіти зазначається: «Держава повинна забезпечувати... розвиток творчих здібностей i навичок самостійного наукового пізнання, самоосвіти і самореалізації особистості» (Національна доктрина розвитку освіти України у XXI столітmі, 2001). У сучасній освіті креативність педагога виступає як один 3 провідних факторів успішності навчання. Креативність $€$ також важливим чинником розвитку особистості, що визначає ії готовність змінюватися і відмовлятися від стереотипів (Дімітрова-Бурлаєнко, 2017). Головною метою педагогічної освіти сьогодні стає підготовка компетентного, кваліфікованого випускника, який здатний не лише застосовувати на практиці знання, вміння і навички, а й приймати оригінальні та нестандартні, креативні рішення в ситуаціях, що виникають у професійній діяльності.

Аналіз найвагоміших публікацій, у яких започатковано розв'язання досліджуваної проблеми. Аналіз психолого-педагогічної літератури показав, що одні науковці розуміють креативність як особливість інтелекту, інші - як специфічну потребу людини у пошуково-перетворювальній діяльності, а деякі взагалі ототожнюють іiі 3 творчістю. Сьогодні не існує єдності щу визначенні природи креативності, тому часто науковці розглядають ії як створення людиною нових, оригінальних ідей щодо управлінської практики, які мають велике значення для розвитку організації. Інші пов’язують креативність із діяльністю людини, спрямованою на самовираження, прагненням зміни статусу та піднесення на вищий службовий щабель (Мала, 2011).

Разом із тим, серед існуючої різноманітності поглядів можна визначити спільні наукові позиції учених щодо аналізованого феномену. Так, дослідники характеризують поняття креативності таким чином: загальна здатність до творчої діяльності (Л. Єрмолаєва-Томіна, С. Сисоєва, О. Ярошинська, Л. Байтімерова, В. Дружинін, Л. Пузеп, О. Кононко, О. Куцевол, В. Фрицюк, І. Подорожна, О. Приходько, Л. Виготський, К. Батовріна, К. Корнолович, С. Попек, В. Лімонт, Й. Кауфман); спеціальна властивість особистості (Дж. Гілфорд, Е. Торренс, С. Гергель); здатність особистості виходити за межі заданої ситуації, створювати оригінальні цінності (Ф. Баррон, Д. Богоявленська, С. Медник, В. Моляко, В. Сластьонін, Л. Байтімерова, Л. Пузеп, О. Кульчицька, І. Гриненко, О. Дунаєва, Н. Добровольська, Н. Вишнякова, І. Шахіна, Л. Виготський, Е. Фромм); процес прояву власної індивідуальності (О. Яковлєва, О. Войтенко, К. Шмідт); обов'язкова характеристика представника педагогічної професії (О. Антонова, С. Сисоєва, О. Куцевол, І. Подорожна, А. Шадріна, І. Гриненко, О. Дунаєва, А. Морозов, В. Фрицюк) (Павленко, 2015).

Вирізнення досі не вирішених аспектів розглядуваної проблеми. Попри наявність досить великої кількості публікацій, поняття креативності й технології ії розвитку сьогодні залишається недостатньо вивченим. Сучасні науковці намагаються досліджувати його теоретичні й методичні засади, визначати його структурні складники, розробляти діагностику креативних можливостей індивіда тощо. Особливої гостроти проблема розвитку креативності майбутніх учителів, у тому числі й математики, набуває в умовах нової української школи, інклюзивної освіти, формування конкурентоздатної, мобільної особистості тощо. Дана публікації присвячена генезі поняття креативності, адаптована на майбутнього педагога.

Метою статті є дослідження генези поняття креативності особистості з античних часів до сьогодення та аналіз. можливостей розвитку креативності майбутніх учителів.

Виклад основного матеріалу 3 повним обгрунтуванням отриманих наукових результатів. Творчі вияви людини здавна првертали увагу не лише самі по собі, а й у пошуку їхнього джерела. У античні часи Платон вважав, що людина отримує ідеї від богів та є їхнім провідником у життя. Аристотель міркував про витоки натхнення як результат розумових асоціацій людини.

У XVIII столітті виникли філософські суперечки про генія, зокрема, про витоки творчого генія. У. Дафф схилявся до теорії генетичної природи креативності. У 1767 році він відрізняв творчий геній від таланту, який характеризується високим рівнем досягнень, але не обов'язково оригінальним мисленням. За його поглядами, творчий геній виникає в результаті вродженої здатності, яка містить асоціативну уяву, що дозволяє комбінувати й оцінювати ідеї та естетичні якості, які спрямовують пошук ідей. Таким чином, поступово формувалося уявлення про креативність як особливу форму геніальності, відмінну від таланту і яка визначається генетичними і середовищними факторами. Надприродний аспект креативності поступово зник з наукового аналізу.

У XIX столітті все більше авторів підтримують ідеї, що геніальність грунтується на найвищому рівні оригінальності, яка, в свою чергу, залежить від здатності встановлювати асоціації між ідеями (Albert, Runco, 1999).

Прийнято вважати, що основоположником дослідження феномену та явища креативності $\epsilon$ англійський вчений XIX ст. Ф.Гальтон, який у 1850-х роках, натхненний ідеями свого кузена Ч. Дарвіна, захопився ідеями спадковості таланту. Впродовж наступних 40 років він послідовно досліджував природу, розвиток, діагностику людських здібностей. При цьому всі свої зусилля він концентрував на дослідженні кількох основних проблем, зокрема, на виявленні факторів, що визначають здібності людини. Ф. Гальтону вдалося виділити два основні такі фактори: спадковість та середовище. Причому, пріоритетність він закріпив за спадковістю, оскільки вважав, що талант $є$ спадковою ознакою і що соціальна еліта формується на основі успадкованого таланту. Така зосередженість пояснювалась тим фактом, що творчі здібності вважались обумовленими рівнем саме інтелекту, хоча численні емпіричні дослідження свідчили про сумнівність цієї гіпотези. 
До початку ХХ століття дослідженнями креативності займалися багато авторів і цілі наукові школи. Так, Едуард Тулуз досліджує видатних людей, таких як Еміль Золя і Анрі Пуанкаре. Він вивчає різні аспекти (сприйняття, пам'ять, мислення, особистісні якості) психологічного функціонування цих людей для того, щоб, зокрема, з'ясувати, чи не пов'язана креативність з певною психологічною крихкістю. Альфред Біне проводить дослідження окремих випадків в області літературної творчості. Він розглядає творче мислення на основі асоціацій як частину інтелекту (Примуш, 2014).

Г. Айзенк розмірковував про феномен психотизму, обумовлюючи креативність та різні форми психопатологій спільною генетичною основою. У 1900 році Т. Рибо у своїх дослідженнях вивчає роль інтелекту, емоцій і несвідомого у творчому мисленні, а також відстежує хід його розвитку та різні форми його прояву - літературну, наукову, підприємницьку. В 1926 році К. Кокс провела біографічне дослідження 300 людей, відомих завдяки їхнім творчим роботам. Вона показала, що високий інтелект (середній IQ досліджених людей дорівнював 154) в поєднанні 3 мотивацією і певними рисами характеру є важливим фактором, що визначає рівень креативності (Семенюк, 2015).

Уперше термін «креативність» було вжито психологом Д. Сімпсоном у 1922 році. Учений вважав, що «креативність» - це здатність людини відмовитися від стеоретипних способів мислення, «здатність до руйнування загальноприйнятого, звичайного порядку походження ідей у процесі мислення» (Курочкина, 2009, с. 632).

Одне з найперших визначень креативності надав американський учений, професор Стенфордського університету Джон Као: «Креативність - це цілісний процес генерації ідей, їх розвитку та перетворення на цінності. Цей процес поєднує в собі те, що люди називають новаторством» (Павленко, 2015).

Незважаючи на тривалу історію застосування терміну, креативність як окреме поняття було виділено лише в 60х pp. ХХ ст. завдяки Дж. Гілфорду. У 1960 році саме цей вчений у зверненні при вступі на посаду президента Американської психологічної асоціації запропонував психологам зосередити свою увагу на вивченні креативності. Були створені декілька лабораторій та інститутів, стали виходити часописи і монографії, однак, за оцінками Р. Стернберга, усього лише 0,5\% статей (із 1975 по 1995 рік) мали відношення до проблеми креативності. Однією 3 причин такого ставлення до проблеми креативності з боку психологів-експериментаторів була нечіткість у визначенні поняття і відсутність методик ії діагностування. Дж. Гілфорд вважав, що креативність - це здатність відмовлятися від стереотипних способів мислення. Саме після публікації його робіт, у яких він визначає різницю між двома типами мисленнєвих операцій - конвергенцією і дивергенцією, концепція креативності набула широкої популярності та почала активно опрацьовуватися (Гилфорд, 1965).

Серед творців теорій креативності найбільш відомим $є$ американський психолог Е. Торренс, що почав свої дослідження креативності в 1958 році й присвятив цій проблемі все життя. Е. Торренс визначав креативність як процес появи чутливості до проблем, дефіциту знань, їхньої невідповідності, дисгармонії та ін.; фіксації цих проблем; пошуку рішень даних проблем, висунення гіпотез; перевірок, змін і повторних перевірок гіпотез; формулювання результату (Torrance, 1974, с. 88).

У цей же час Д. Маккіннон, К. Роу та інші дослідники з Інституту з вивчення і вимірювання особистості вивчали особистісні риси і мотиви, пов'язані з креативністю. У їхніх дослідженнях застосовували кореляційні методи і методи порівняння груп із різним рівнем креативності. Було показано, що з креативністю може бути пов'язано багато рис: впевненість у собі, незалежність суджень, схильність до ризику. Для А. Маслоу і К. Роджерса креативність є засобом реалізації свого потенціалу (самоактуалізація), вона пов'язується 3 такими рисами, як розуміння себе і свобода духу (Любарт, Муширу, Торджман, \& Зенасни, 2009).

Послідовниками Дж. Гілфорда й Е. Торренса є М. Волах і Н. Коган, які відкинули один із критеріїв креативності - точність. Учені відмовилися від обмеження часу, середовища конкуренції та єдиного критерію правильної відповіді. Вони вважають, що креативність та інтелект взаємопов'язані не тільки на рівні якостей особистості, але й на рівні цілісного пізнавального процесу (Дружинин, 2008, с. 190).

Глибокий науковий інтерес у контексті проблеми креативності викликає «теорія інвестування», запропонована Р. Стернбергом і Д. Лавертом. Автори вважають креативними таких людей, які здатні «купувати ідеї за низькою ціною і продавати за високою». У цій концепції проявилися особистісні характеристики самого Р. Стернберга, автора і співавтора більш ніж 600 публікацій із проблем інтелекту, креативності, здібностей. «Купувати за низькою ціною» означає займатися невідомими, невизнаними або малопопулярними ідеями. Завдання полягає в тому, щоб правильно оцінити потенціал їхнього розвитку і можливий попит. Творча людина, всупереч опору середовища, нерозумінню і неприйняттю, наполягає на визначених ідеях і «продає їх за високою ціною». Після досягнення ринкового успіху вона переходить до іншої непопулярної або нової ідеї (Стернберг, 1976).

За теорією креативності Р. Стернберга, розвиток творчої активності особистості забезпечується наявністю таких взаємопов'язаних компонентів: 1) здібності, які поділяються на синтетичні (уміння по-новому бачити проблему, дивергентне мислення), аналітичні (уміння аналізувати й оцінювати ідеї), практично-контекстуальні (уміння знаходити абстрактним ідеям практичне застосування); 2) знання, спираючись на які людина може перейти до творчої діяльності, креативно використовувати теоретичні відомості на практиці; 3) мислення (дослідники наголошують, що найважливішим для творчості $€$ «законодавчий» стиль, спрямований на власні закони руху й розвитку думки); 4) особистісні якості, серед яких найважливішими є вміння долати перепони й невпевненість, виправдано ризикувати; 5) мотивація, що допомагає людині зосередитися на творчій роботі; 6) оточуюче середовище, оскільки без підтримки середовища креативність не може виявлятися і розвиватися. Отже, креативність, за Р. Стернбергом, є процесом деталізації творчого продукту та надання йому конкретної предметної форми (Taylor, \& Sternberg, 1988, с. 99).

У 1980-х і 1990-х роках питання про зв'язок креативності з конативними змінними продовжує привертати увагу фахівців із соціальної психології креативності. Так, у 1996 році Амабілія з співробітниками досліджує роль внутрішньої мотивації в креативності. Інші дослідження присвячуються впливу культурного середовища. У 1984 році 
Саймонтон у своїх «історіометричних» дослідженнях встановив, що певні характеристики суспільства, такі як політичне різноманіття, впливають на креативність його членів протягом усього історичного розвитку (Amabile, 1996).

Науковий інтерес для розуміння розвитку творчості особистості становить концепція механізму творчості, яку розробив вітчизняний учений В. Клименко. Основна проблема, що ії досліджує автор концепції механізму творчості людини (креативної психічної системи), формулюється так: «Здібності людини виявляються не в тому, що вона має знання у формі знакових систем, відчуває у формі почувань, а в тому, що вона доцільно діє, спираючись на логіку предмета». Автор концепції креативної психічної системи людини стверджує: «Механізм творчості проявляється тільки в дії. Його не варто відшукувати ані в особливостях будови мозку, ані в конституції тіла, ані в точності й гостроті ока, ані в тонкощах слуху, ані в здібностях, ані в можливостях пам'яті. Тому ми відкидаємо думку про елітарність механізму творчості. Цим обгрунтовується проста для кожної людини думка: кожний носить у собі креативну психічну систему (механізм творчості)» (Клименко, 2006, с. 53).

У зарубіжних дослідженнях Е. Торренс трактував креативність як здатність до загостреного сприйняття недоліків, прогалин у знаннях, відчуття дисгармонії. Його тести (ТТСТ) були створені в руслі концепції дивергентного мислення Гілфорда. Однак Торренс орієнтувався передусім не на стимуляцію творчих здібностей, а на результати факторно-аналітичних досліджень. Креативність він вважав загальною здатністю, яка грунтується на поєднанні загального інтелекту, особистісних характеристик і здібностей до продуктивного мислення (Томаков, 2006).

Сучасний вітчизняний педагог, науковець С. Овчаров, вивчаючи технології розвитку креативності вчителів інформатики, розглянув низку методик оцінки креативності учителів. У своїх наукових публікаціях він пропонує креативність учителів інформатики оцінювати на основі загальних і спеціальних критеріїв креативності. На його думку, до загальних критеріїв креативності належать такі: асоціативність, гнучкість мислення, здатність до перекомбінування, інтуїтивність, оригінальність, побіжність думки. На думку вченого, під час оцінки креативності вчителів-предметників слід звертати увагу на спеціальні критерії креативності, під якими він розуміє показники, які властиві вчителям конкретної спеціальності, що визначають їхню готовність до творчої діяльності в процесі навчання предмету. Вони характеризують здатність педагога креативно підходити до викладання шкільного курсу певної дисципліни, навчати учнів цій дисципліні на основі використання евристичних прийомів і методів, формувати й розвивати в них потужний креативний потенціал. Автор пропонує процес професійної підготовки вчителів розглядати в контексті неперервної професійної освіти та організовувати його на основі широкого використання комп'ютерної техніки (Овчаров, 2017).

Іншою часто використовуваною методикою вимірювання креативних здібностей людини є тест віддалених асоціацій С. Медніка на вербальну креативність (Mednick, 1962, с. 229). У тесті використовується сорок словесних тріад. Елементи кожної тріади належать до взаємно віддалених асоціативних галузей. Опитуваним пропонується три слова. Необхідно підібрати до них таке четверте, яке б підходило до кожного з трьох слів, тобто могло б скласти словосполучення з кожним із трьох слів-стимулів. Наприклад: швидкий, зелений, повний. Відповіддю може бути «поїзд». Цей тест можна використовувати для вимірювання креативності вчителів інформатики на основі таких критеріїв: асоціативність, оригінальність та інтуїтивність. На наш погляд, цей метод є зручним у використанні, але потребує певного підготовчого етапу та вимагає ретельної обробки отриманих результатів, зазвичай, із залученням фахівців-психологів (Овчаров, 2017).

Протягом останніх двадцяти років простежується розвиток когнітивного підходу до креативності. Експерименти, дослідження окремих випадків і моделювання за допомогою штучного інтелекту дозволяють вивчати ментальні репрезентації, а також задіяні в творчості процеси перетворення інформації (породження аналогій, пошук, розробка і синтез ідей). На думку деяких представників когнітивного підходу, креативність грунтується на звичайних когнітивних процесах, навіть якщо результати цих процесів виявляються «незвичайними».

Таким чином, більшість сучасних учених прихильні до теорій, відповідно до яких креативність є результатом конвергенції когнітивних, конативних і середовищних факторів, що й визначає напрями пошуку шляхів їі розвитку (Томаков, 2006).

Висновки 3 дослідження та перспективи подальшої розробки цього тематичного напрямку. Простежуючи динаміку визначення поняття креативності особистості з античних часів до сьогодення, ми проаналізували погляди педагогів і психологів щодо феномену креативності і з'ясували сучасні погляди на їі сутність і природу. Подальшу роботу в даному напрямі дослідження вбачаємо в розробці системи розвитку креативності майбутніх учителів, зокрема математики, в процесі фахової підготовки.

\section{Список використаних джерел}

Гилфорд, Дж. (1965). Три стороны интеллекта. В кн. А. М. Матюшин (Ред.), Психология мышления (С. 443-456). Москва: Прогресс.

Державна національна програма “Освіта” (Украӥна ХХІ століття). (1994). Київ: Райдуга.

Дімітрова-Бурлаєнко, С. Д. (2017). Генеза поняття «креативна компетентність»у контексті психолого-педагогічних досліджень. Педагогіка та психологія, 58, 3-14.

Дружинин, В. Н. (2008). Психология общих способностей. Санкт-Петербург: Питер.

Клименко, В. В. (2006). Психологія творчості: навч. посіб. для студ. вищих навч. закладів Київ: Центр навчальної літератури. 
Курочкина, А. Ю. (2009). Исследования креативности: постановка проблемы экономики. В кн. Н. А. Горелов, О. Н. Мелькова (Ред.), Сборник научных статей по итогам Международной научной конференичи (С. 630-639). Москва: Креативная экономика.

Любарт, Т., Муширу, К., Торджман, С., \& Зенасни, Ф. (2009). Психология креативности. Москва: Когито-Центр.

Мала, Н. Т. (2011). Креативність як складова ефективного управління. Вісник Національного університету «Львівська політехніка», 704, 18-23. Взято з http://ena.lp.edu.ua:8080/handle/ntb/12412.

Національна доктрина розвитку освіти України у XXI столітті. (2001). Педагогічна газета, 7 (85).

Овчаров, С. М. (2017). Розвиток креативності вчителів інформатики в системі неперервної професійної освіти. В кн. В. В. Владыкина, Г. А. Гилев, Н. А. Гиренко, ... Л. Г. Юсупова. Наука и инновации в современном мире: образование, воспитание, физическое воспитание и спорт (Кн. 2, С. 8-22). Одесса.

Павленко, В. В. (2016). Суб’єкт-суб'єктна взаємодія у навчально- виховному процесі Польщі. В кн. М. Чепіль (Ред.), Людинознавчі студіï: зб. наук. праць Дрогобицького держ. пед. ун-ту імені Івана Франка. Серія "Педагогіка" (Вип. 2/34, С. 184-196). Дрогобич.

Павленко, В. В. (2015). Креативність учителя як чинник розвитку педагогічної творчості. В кн. В. Є. Литньова, Н. Є. Колесник, Т. В. Наумчук (Ред.), Формування дидактичної компетентності педагогів дошкільної та початкової освіти: зб. наук.-метод. праць (С. 145-150). Житомир: Вид-во ЖДУ ім. І. Франка.

Примуш, Р. Б. (2014). Управління креативністю державних службовців. Державне управління: удосконалення та розвиток, 5. Взято 3 http://nbuv.gov.ua/UJRN/Duur_2014_5_4.

Семенюк, М. Ю. (2015). Теоретичні засади проблеми розвитку креативності обдарованих студентів. Освіта та розвиток обдарованої особистості, 7, 27-30.

Стернберг, Р. (1976). Модель структуры интеллекта Гилфорда: структура без фундамента. В кн. Д. Б. Богоявленская (Ред.), Основные современные концепции творчества и одаренности (С. 111-127). Москва: Молодая гвардия.

Томаков, В. И. (2006). Модель специалиста в контексте профессиональных компетенций и качеств личности. Вестник Воронежского гос. техн. ун-та, 2, 10, 98-102.

Albert, R. S., \& Runco, M. A. (1999). A history of research on creativity. In R. J. Sternberg, Handbook of creativity (pp. 16-31). New York: Cambridge University Press.

Amabile, T. M. (1996). Creativity and Innovation in Organizations. Harvard Business School Background.

Mednick, S. A. (1962). The associative basic of the creative process. Psychological review, 69, 2, 220-232.

Taylor, C. W., \& Sternberg, R. J. (1988). Various Approaches to and Definitions of creativity. Cambridge: Cambridge Univ. Press.

Torrance, E. P. (1974). The Torrance Test of creative thinking: Technical-norm manual.

\section{References}

Albert, R. S., \& Runco, M. A. (1999). A history of research on creativity. In R. J. Sternberg, Handbook of creativity (pp. 16-31). New York: Cambridge University Press.

Amabile, T. M. (1996). Creativity and Innovation in Organizations. Harvard Business School Background.

Gilford, Dzh. (1965). Tri storony intellekta [Three sides of intelligence]. In A. M. Matiushin (Ed.), Psikhologiia myshleniia [Psychology of Thinking] (pp. 443-456). Moskva: Progress [in Russian].

Derzhavna nacional na programa «Osvita» (Ukrayina XXI stolittya). (1994). [State National Program "Education" (21st Century Ukraine)]. Kyiv: Rajduga [in Ukrainian].

Dimitrova-Burlaienko, S. D. (2017). Geneza poniattia "kreatyvna kompetentnist" u konteksti psykholoho-pedahohichnykh doslidzhen [Genesis of the concept of "creative competence" in the context of psychological and pedagogical research]. Pedahohika ta psykholohiia [Pedagogy and Psychology], 58, 3-14 [in Ukrainian].

Druzhinin, V. N. (2008). Psikhologiia obshchikh sposobnostei [Psychology of General Abilities]. Sankt-Peterburg: Piter [in Russian].

Klymenko, V. V. (2006). Psykholohiia tvorchosti [The Psychology of Creativity]: navch. posib. dlia stud. vyshchykh navch. zakladiv Kyiv: Tsentr navchalnoi literatury [in Ukrainian].

Kurochkina, A. Iu. (2009). Issledovaniia kreativnosti: postanovka problemy ekonomiki [Studies of creativity: statement of the problem of economics]. In N. A. Gorelov, O. N. Melkova (Eds.), Sbornik naukovykh statei po itogam Mezhdunarodnoi nauchnoi konferentcii [Sbornik nauchnykh statei po itogam Mezhdunarodnoi nauchnoi konferentcii] (pp. 630-639). Moskva: Kreativnaia ekonomika [in Russian].

Liubart, T., Mushiru, K., Tordzhman, S., \& Zenasni, F. (2009). Psikhologiia kreativnosti [Psychology of creativity]. Moskva: Kogito-Tcentr [in Russian].

Mala, N. T. (2011). Kreatyvnist yak skladova efektyvnoho upravlinnia [Creativity as a Component of Effective Governance]. Visnyk Natsionalnoho universytetu "Lvivska politekhnika" [Bulletin of the National University "Lviv Polytechnic"], 704, 18-23. Retrieved from http://ena.lp.edu.ua:8080/handle/ntb/12412 [in Ukrainian]. 
Mednick, S. A. (1962). The associative basic of the creative process. Psychological review, 69, 2, 220-232.

Natsionalna doktryna rozvytku osvity Ukrainy u XXI stolitti [National doctrine of development of education of Ukraine in the XXI century]. (2001). Pedahohichna hazeta [Pedagogical newspaper], 7 (85) [in Ukrainian].

Ovcharov, S. M. (2017). Rozvytok kreatyvnosti vchyteliv informatyky v systemi neperervnoi profesiinoi osvity [Development of creativity of teachers of informatics in the system of continuous professional education]. In V. V. Vladukyna, H. A. Hylev, N. A. Hyrenko, ... L. H. Yusupova. Nauka y ynnovatsyy v sovremennom myre: obrazovanye, vospytanye, fyzycheskoe vospytanye y sport [Science and innovations in the modern world: education, upbringing, physical education and sport] (Bok. 2, pp. 8-22). Odessa [in Ukrainian].

Pavlenko, V. V. (2016). Sub'iekt-sub'iektna vzaiemodiia u navchalno-vykhovnomu protsesi Polshchi [Subject-subject interaction in the educational process of Poland]. In M. Chepil (Ed.), Liudynoznavchi studii: zb. nauk. prats Drohobytskoho derzh. ped. un-tu imeni Ivana Franka. Seriia "Pedahohika" [Human Studies: Coll. Sciences. works of Drohobych Ivan Franko State Pedagogical University] (Is. 2/34, pp. 184-196). Drohobych [in Ukrainian].

Pavlenko, V. V. (2015). Kreatyvnist uchytelia yak chynnyk rozvytku pedahohichnoi tvorchosti [Teacher creativity as a factor in the development of pedagogical creativity]. In V. Ye. Lytnova, N. Ye. Kolesnyk, T. V. Naumchuk (Eds.), Formuvannia dydaktychnoi kompetentnosti pedahohiv doshkilnoi ta pochatkovoi osvity [Formation of didactic competence of teachers of preschool and primary education]: zb. nauk.-metod. prats (pp. 145-150). Zhytomyr: Vyd-vo ZhDU im. I. Franka [in Ukrainian].

Prymush, R. B. (2014). Upravlinnia kreatyvnistiu derzhavnykh sluzhbovtsiv [[Public servants' creativity management]. Derzhavne upravlinnia: udoskonalennia ta rozvytok [Public administration: improvement and development], 5. Retrieved from http://nbuv.gov.ua/UJRN/Duur_2014_5_4[in Ukrainian].

Semeniuk, M. Yu. (2015). Teoretychni zasady problemy rozvytku kreatyvnosti obdarovanykh studentiv [Theoretical foundations of the problem of development of creativity of gifted students]. Osvita ta rozvytok obdarovanoi osobystosti [Education and development of gifted personality], 7, 27-30 [in Ukrainian].

Sternberg, R. (1976). Model struktury intellekta Gilforda: struktura bez fundamenta [Guilford's intelligence structure model: a structure without foundation]. In D. B. Bogoiavlenskaia (Ed.), Osnovnye sovremennye kontceptcii tvorchestva $i$ odarennosti [Basic modern concepts of creativity and giftedness] (pp. 111-127). Moskva: Molodaia gvardiia [in Russian].

Taylor, C. W., \& Sternberg, R. J. (1988). Various Approaches to and Definitions of creativity. Cambridge: Cambridge Univ. Press.

Tomakov, V. I. (2006). Model spetcialista v kontekste professionalnykh kompetentcii i kachestv lichnosti [Specialist model in the context of professional competencies and personality traits]. Vestnik Voronezhskogo gos. tekhn. un-ta [Vestnik Voronezhskogo gos. tekhn. un-ta], 2, 10, 98-102 [in Russian].

Torrance, E. P. (1974). The Torrance Test of creative thinking: Technical-norm manual.

\section{BURCHAK S.}

Oleksandr Dovzhenko Hlukhiv national pedagogical university, Glukhiv, Ukraine

\section{GENESIS OF THE PROBLEM OF CREATIVITY IN PSYCHOLOGICAL-PEDAGOGICAL SCIENCE}

The article deals with the process of formation of the concept of personality creativity, technologies of its development and diagnosis from ancient times to the present. Psychological and pedagogical literary sources are analyzed in order to identify different approaches to the interpretation of the concept of "creativity".

Examples of normative documents of Ukraine, which discusses the need to develop creativity of the nation, are given, as well as the main purpose of pedagogical education: a competent, qualified graduate who is able not only to apply knowledge, skills and skills, but also to make original and non-standard, creative decisions. in situations that arise in professional activity.

The common scientific positions of scientists on the interpretation of the concept of creativity among a large number of views are determined.

The approaches of scientists to defining the concept of creativity, its structural constituents (components), methods of assessing the level of development of individual creative qualities of a person, including pedagogical workers from ancient times to the present, are considered.

The fact that philosophical disputes about genius, in particular, about the origins of creative genius, arose in the eighteenth century, and in the nineteenth century, more and more authors supported the idea that genius is based on the highest level of originality, which depends on the ability to establish associations between ideas.

It has been found that the cognitive approach to creativity has been traced in recent years. Experiments, case studies, and artificial intelligence modeling allow us to study mental representations, as well as the processes involved in the creation of information (creation of analogies, search, development and synthesis of ideas). Most modern scholars emphasize that during this period a number of theories have been proposed, according to which creativity is the result of the convergence of cognitive, connective, and environmental factors.

Keywords: genesis of the problem of creativity; psychological and pedagogical science; creativity of a person; methodology for assessing creativity; components of creativity; creativity of a future teacher

Стаття надійшла до редакції 27.10.2019 р. 